\title{
Local wisdom of Talang Mamak Tribe, Riau, Indonesia in supporting sustainable bioresource utilization
}

\author{
PRIMA WAHYU TITISARI ${ }^{1, \bullet}$, ELFIS $^{1}$, IRINA SAFITRI ZEN ${ }^{2}$, KHAIRANI $^{1}$, NADIATUL JANNA ${ }^{1}$, \\ NUNUT SUHARNI', TIKA PERMATA SARI ${ }^{1}$ \\ ${ }^{1}$ Department of Biology, Faculty of Education, Universitas Islam Riau. Jl. Kaharuddin Nasution No. 113, Marpoyan, Pekanbaru 24284, Riau, Indonesia. \\ Tel.: +62.761.674.674 Fax.: +62.761.674.834, `email: pw.titisari@edu.uir.ac.id, pw.titisari@gmail.com \\ ${ }^{2}$ Centre for Innovative Planning \& Development, Sustainability Research Alliance, Universiti Teknologi Malaysia. 81310 Skudai, Johor, Malaysia
}

Manuscript received: 27 October 2018. Revision accepted: 16 December 2018.

\begin{abstract}
Titisari PW, Elfis, Zen IS, Khairani, Janna N, Suharni N, Sari TP. 2019. Local wisdom of Talang Mamak Tribe, Riau, Indonesia in supporting sustainable bioresource utilization. Biodiversitas 20: 190-197. Study the Talang Mamak tribe is an isolated community that lives traditionally in the downstream Indragiri River, Riau Province, Indonesia. This tribe is one of the oldest Malay tribes (Proto Malay), relatively still maintaining hunting and gathering mode of life even though now some of them began to settle and farm. The study aims to identify their local wisdom and analyze it in the context of bioresource utilization to sustain their living needs. Data were collected through observation, interviews, documentation, and triangulation. The informants to be interviewed were selected using purposive sampling. The study showed that the local wisdom of Talang Mamak Tribe had sustainable dimension in managing bioresources which inherited from their ancestors. This cultural heritage guides the community to always live in harmony with the universe which is reflected in ritual activities such as melambas and basolang menugal (clearing land for farming), manumbai (harvesting timber from the forest) and manjumbai (harvesting honey). Sociologically, the traditions or customs carried out by the Talang Mamak tribe are an effort to preserve and maintain bioresource, so as to create a balance of relations between humans and nature.
\end{abstract}

Keywords: Bioresource, Talang Mamak Tribe, sustainability

\section{INTRODUCTION}

The study on relationship between culture and the environment is very important to understand human contemporary issues. Deforestation issues (Chakravarty et al. 2012; Junior et al. 2018; Mastel et al. 2018; Ojo et al. 2018), biodiversity loss (Díaz et al. 2006; Anil et al. 2014; He et al. 2018; Heilpern et al. 2018), and ecosystem degradation (Hussein 2008; Tyagi et al. 2014) are closely related to humans, both as causes and recipients of impacts.

Talang Mamak is one of the indigenous tribes located in Bukit Tigapuluh National Park (TNBT), Indragiri Hulu Regency, Riau and Jambi Provinces, Indonesia. The Talang Mamak community occupies the traditional use zone of TNBT. The population is estimated to be \pm 3341 families or \pm 9418 people, spread in 5 (five) sub-districts, namely Rakit Kulim Sub-district, Batang Gansal Sub-district, Batang Cenaku Sub-district, Rengat Barat Sub-district, and Seberida Sub-district. A very strong and long-lasting interaction between the community and their environment manifest in various local culture in managing and utilizing bioresource. Forests, according to them, function as inherited habitats that must be maintained and for the survival of the community. Hence, developing ecological culture based on the local wisdom to guide forest management is very important.

Furthermore, the local wisdom of the Talang Mamak community in farming shown in its comprehensive approaches range from forest clearing for farmland to postharvest handling. Farming activity conducts by considering its source for food security and the economic support in life. The wisdom values in farming derived from ancestors for generations shows in the principle harmony of nature through their customs. High dependency of Talang Mamak community with nature shows in a place to live, carry on life, produce, interact and socialize (Singleton 1998; Gilung 2012; Muntaza 2014; Ade and Affandi 2016; Mauludea 2016).

The complexities of Talang Mamak tribe shown in its hierarchal society. The tribe is divided into several subgroups called as suku, then divided into tobo and the smallest unit is called hinduk or perut or puak anak. Belongs to the Old Malay tribe (Proto-Malay), the Talang Mamak is an indigenous tribe in the Indragiri River region where people call as "Tuha Tribe". The term means that the first tribe came to the Indragiri River. According to Indragiri Resident Assistant, the tribe has originally come from the Pagaruyung area, who moved due to conflict between adat and religion. Meanwhile, based on the myth, the Talang Mamak tribe is the third descendant of Adam from heaven who descended to earth, precisely in the Limau River and settled in Sungai Tunu Hamlet, Talang Durian Cacar Village, Rakit Kulim Sub-district, Indragiri Hulu District, Riau Province, Indonesia. This can be seen from the phrase "Kandal Tanah Makkah, Merapung di Sungai Limau, menjeram di Sungai Tunu", means Their 
ancestors came from Mecca, stranded on the Limau River, then lived in Sungai Tunu" (Singleton 1998; Gilung 2012).

The local wisdom of the Talang Mamak community in managing resources is essentially based on a religious system that guides and exemplifies in their harmonious relationship with the dynamics of the universe. Some of illogical practices are their belief that the universe is full of magical powers. This belief implicates to their daily practices such as seeking permission to God or landowners in any work related to forest utilization. Sociologically their tradition is solely an effort to preserve the environment, so as to create a balance of relations between humans and their natural environment. Traditional wisdom possessed by Talang Mamak community, especially in managing resources, needs attention from various parties to preserve it, because it is traditional value rooted in national culture (Islamuddin 2014; Muntaza 2014; Ade and Affandi 2016; Mauludea 2016). The purpose of this study was: (i) to find out the forms of local wisdom carried out by the Talang Mamak community in farming (ii) to analyze the meaning of local wisdom in maintaining ecosystems.

\section{MATERIALS AND METHODS}

\section{Study area}

This research activity was carried out from April to August 2018 located in the Bukit Tigapuluh National Park (TNBT), Indragiri Hulu District, Riau Province, Indonesia with a focus on data collection in five villages in Rakit Kulim Subdistrict, namely Talang Selantai Village $\left(0^{\circ} 62^{\prime} 01.93\right.$ "S, $\left.102^{\circ} 19^{\prime} 77.37^{\prime} \mathrm{W}\right)$, Talang Perigi Village $\left(0^{\circ} 56 ' 30.56\right.$ "S, 102²0'58.61" W), Talang Gedabu Village (051'44.36 "S, 102 22'00. 60" W), Talang Durian Cacar Village $\left(0^{\circ} 61^{\prime} 16.25\right.$ "S, $102^{\circ} 16^{\prime} 00.44$ "W), and Talang Tujuh Tangga Village $\left(0^{\circ} 72^{\prime} 64.27 " \mathrm{~S}, 102^{\circ} 10^{\prime} 26.05\right.$ "W), as well as four villages in Batang Gangsal Sub-district, namely Siambul Village $\left(0^{\circ} 75^{\prime} 23.30\right.$ "S, 102³8'41.80" W), Rantau Langsat Village $\left(0^{\circ} 85^{\prime} 34.04\right.$ "S, 10243'20.71" W), Sungai Akar Village $\left(0^{\circ} 92^{\prime} 46.14\right.$ " S, 102 $52^{\prime} 77.83$ "W), and Penyaguan Village ( $0^{\circ} 53^{\prime} 00.39^{\prime \prime} \mathrm{S}, 102^{\circ} 66^{\prime} 09.35$ "W). These nine villages are occupied by the Talang Mamak Tribe community.

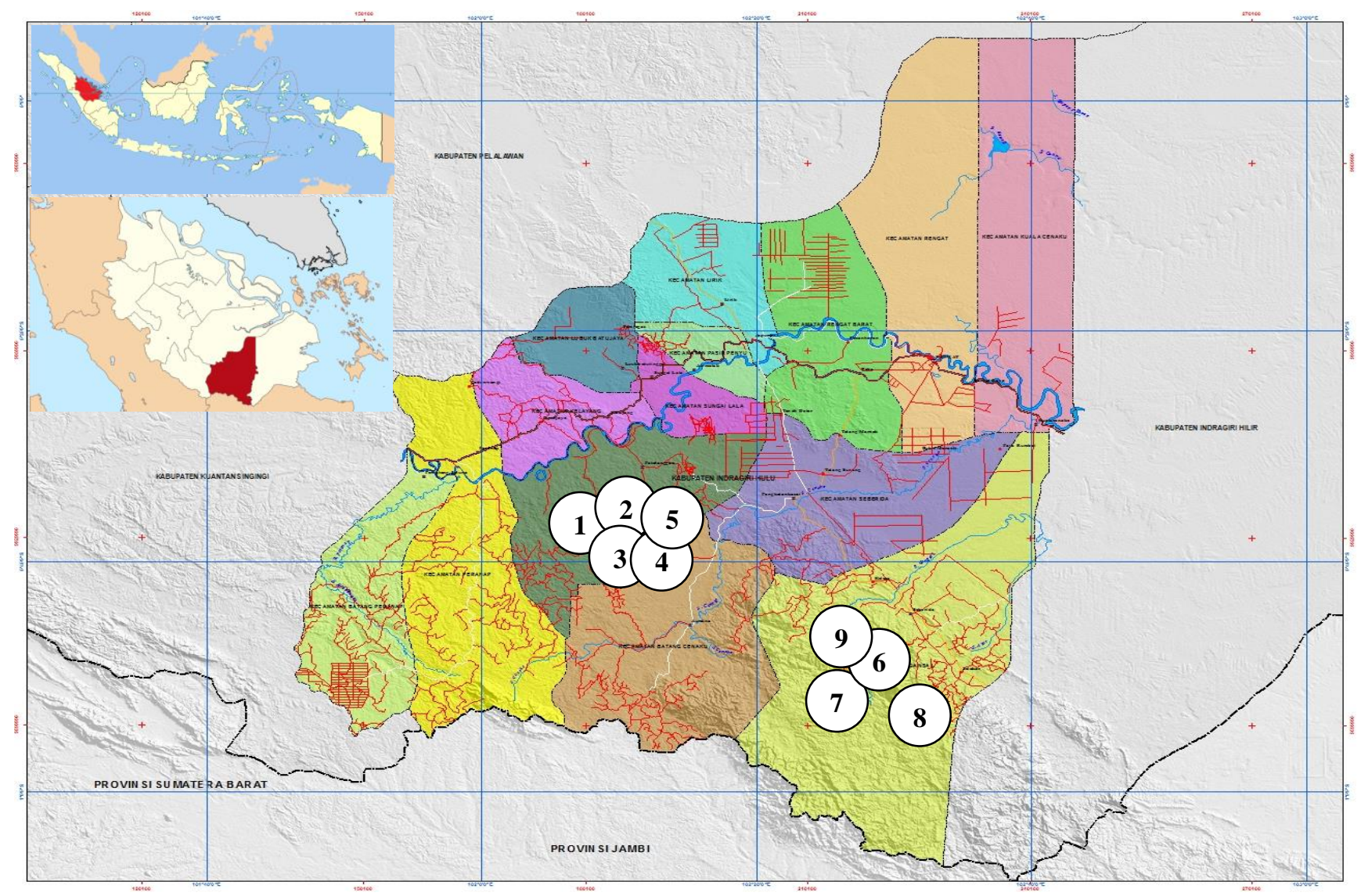

Figure 1. Research site in Indragiri Hulu District, Riau Province, Indonesia. Note: 1. Talang Selantai, 2. Talang Perigi, 3. Talang Gedabu, 4. Talang Durian Cacar, 5. Talang Tujuh Buah Tangga, 6. Siambul, 7. Rantau Langsat, 8. Sungai Akar, 9. Penyaguan 


\section{Research methods}

This study deployed the qualitative approach of ethnographic methods. Ethnographic research focused on the community, by choosing informants who are known to have a broad and deep view of the activities of the community under study. Data were collected through observation, interviews, Focus Group Discussion (FGD) with key informants led by Talang Mamak Tribe, namely Patih and Batin Talang Mamak and community leaders such as Mangku/Monti, Pengulu and Dubalang. In addition to key informants, the FGD was also conducted with the Talang Mamak community group. Data analyses were done in three activities occurring simultaneously, namely data reduction, data display and conclusion drawing/data verification.

\section{RESULTS AND DISCUSSION}

Local communities living in the TNBT area consist of the Talang Mamak Tribe, and the Old Malay Tribe, living permanently along the Batang Gansal River that divides the TNBT area. There are 5 hamlets scattered into 15 settlement concentrations inhabited by the Talang Mamak and Old Malay Tribes along the Batang Gansal River. Administratively, the hamlets are included in Batang Gansal Sub-district, Siberida Sub-district, and Rakit Kulim Sub-district, Indragiri Hulu District, Riau Province. The source of local communities' income of living in the TNBT region comes from rubber plantation products $(61-86 \%)$, non-timber forest products and the results of other activities such as trade and natural tourism (3-14\%) (Santoso 2008). Traditional communities living in TNBT areas have customary regulations that support forest conservation which is realized by the presence of sacred forests around settlements which cannot be managed, such as those found in the Datai Tua and Suit settlements. In addition, local communities have a habit of mutual cooperation in forest resource utilization activities. Most (around 87\%) of the population living in the TNBT buffer zone are Muslim, about $10 \%$ are Christians, most of whom are immigrants from North Sumatra, and about 3\% still hold the traditional religion, who are generally the Talang Mamak community.

For some local communities, forests are an important part of traditional life and in carrying out rituals, because most of the traditional equipment comes from the forest, like other Malay tribes, the Sakai tribe also lives by collecting forest products (Titisari et al. 2016). In addition, forest conception is very important for the Malay and Talang Mamak communities because forests are an important part of cosmology in real and supernatural life. Local people, especially Malays and Talang Mamak, still know some puaka (sacred forest) and also about stories of natural events that can support conservation. Some areas which are guarded and considered haunted are Pintu Tujuh Cave, Tobat Hill, and some puaka areas located along the Gangsal River. The Malay and Talang Mamak communities still have strong customs. They are saying that "let the child die, as long as customs don't die " shows how they celebrate customs above other interests. They also have stories about animals and natural legends around their forests. For example, a tiger is a human child who goes to the forest to control the forest, as well as an elephant is known as a Datuk Lumahan that is perceived to have great power, and a single pig god is a god of fortune and legend of Seven Door tells of the iniquity of a child against his mother.

The TNBT area ecosystem is located on a fairly steep hill area in the middle of the eastern plains of Sumatra Island which is separated from the Bukit Barisan mountain range. Based on differences in stand structure, species composition and physiognomy, in general, TNBT ecosystems can be divided into 4 types, namely (i) Virgin natural forests, namely natural tropical rainforests which have not been disturbed by logging activities. This subecosystem is dominated by the species of Dipterocarpaceae such as Shorea abovoidae and Shorea acuminata, (ii) Logged-over natural forests, i.e., forest areas that have been logged. This sub-ecosystem is dominated by the species of Euphorbiaceae including Elatriospermum tapos and Baccaurea racemosa, (iii) Shrubs, which are forest areas that have been cleared for cultivation and then left to be used as fields in the next period. The species that dominate this sub-ecosystem are generally the pioneer ones, such as Macaranga gigantea and Macaranga triloba, and (iv) Rubber gardens, which are areas used by local communities living in the area for gardening with the main species of rubber plant (Hevea brasiliensis) that grows with other forest plants. The Talang Mamak uses biennial circulation pattern of land use for the cultivation (Figure 2), which makes farming land fertile, because land fertility relies on nutrient input from the decomposition of litter from former crops. The first location to be cleared will be planted again ten years later. Cultivation of farmland with slash technique, tuggal/punching, planting, and punching again. This soil treatment pattern causes the soil to remain loose. Crops that are planted are generally stapled food crops, such as cassava, corn, taro, and rice.

The pattern of forest clearing by the Talang Mamak Tribe, which consists of cleared forests, are then used as gutters/batin (Figure 3). Each existing head of household has a private land consisting of a yard/house (the yard is planted with herbs, medicinal plants, and vegetables for their own household needs), farmland (land planted with staple food crops, such as sweet potatoes, corn, which is used to meet household needs), gardens (generally containing fruit-producing plants, such as durian, mangosteen, $d u k u$, coconut, jernang, and rubber which are used as a source of family economic income). All these three processed lands become family property that can be inherited. Community/tribal groups also have traditional land (ulayat land) in the form of rimba sialang which contains sialang trees where bees nest. The sale of honey from the bee is used for the benefit of the community such as for the cost of inaugurating the Batin and Monti. The other ulayat land is the Rimba Simpanan, which is a forest that is still intact (virgin forest), well maintained and used as a boundary between the allotment areas. Rimba Sialang and Rimba Simpanan are owned by the community which each tribe member must protect, and taking/damaging the 
contents of which gets the consequences of tribal customary law enforcement.

The TNBT area has a high flora wealth with no less than 1500 species of flora are found in it, most of which are the species producing wood, sap, bark, fruit, and medicines. Among several species of flora there are rare, such as muka rimau fungus (Rafflesia hasseltii), salo (Johannesteijsmannia altifrons), mapau (Pinanga multiflora), mapau kalui (Iguanura wallichiana), jelutung (Dyera costulata), Calamus ciliaris, Calamus exilis, ramin (Gonistylus bancanus), kemenyan (Styrax benzoin), pasak bumi (Eurycoma longifolia), pinang bacung (Nenga gajah), kabau tupai (Archidendron bubalinum), akar mendera (Phanera kochiana), Shorea pelatata, keduduk rimba (Baccaurea racemosa), and silima tahun (Baccaurea stipulata) (BBKSDA Riau 2013).

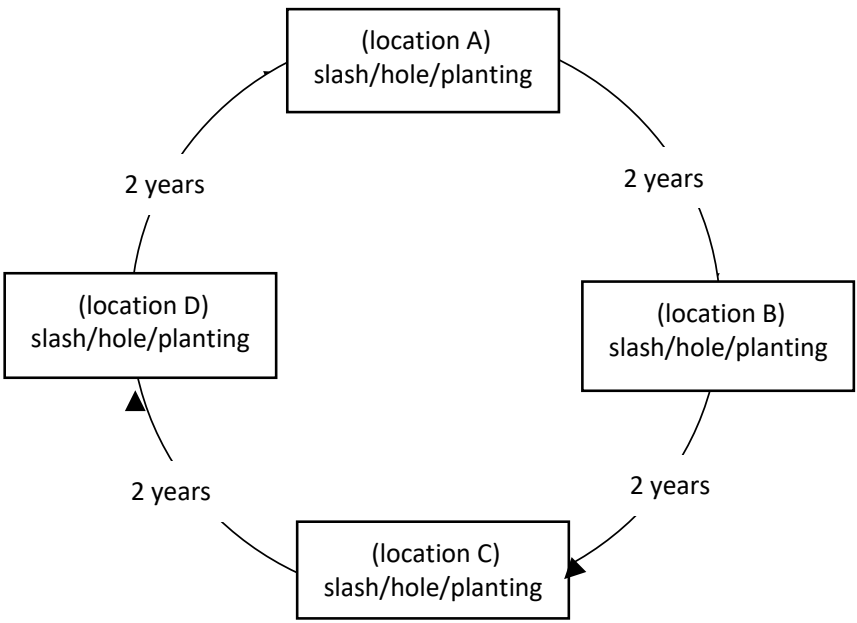

Figure 2. Circulation pattern of land use for cultivation by Talang Mamak Tribe, Riau Province, Indonesia

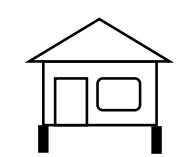

1

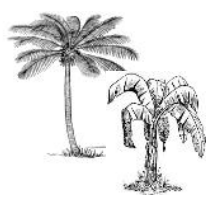

2

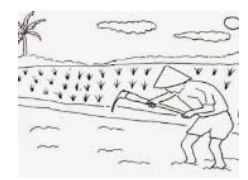

3

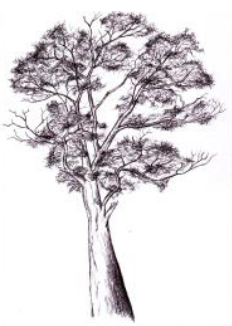

4

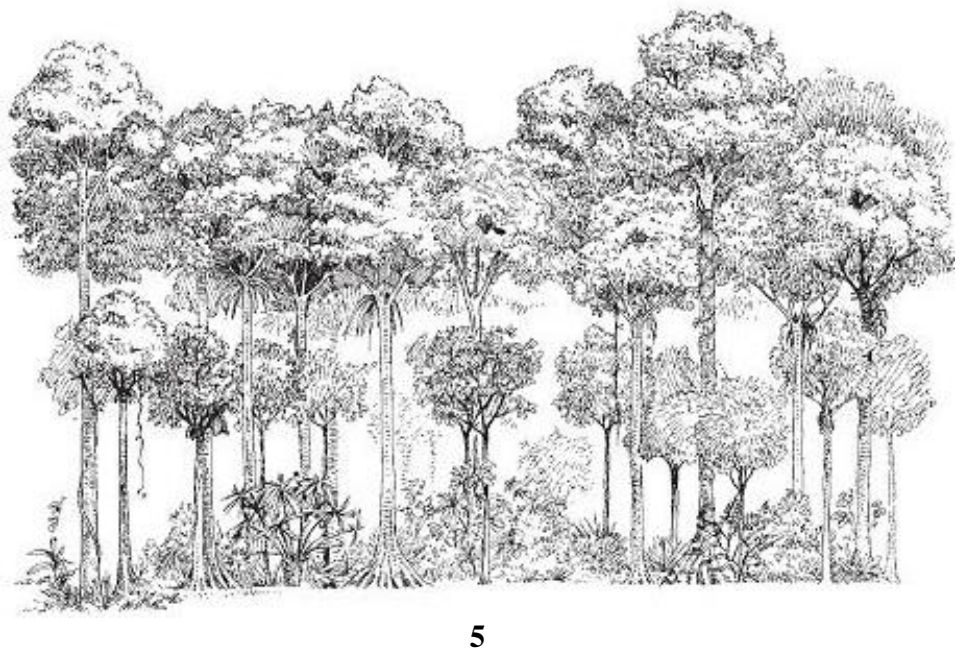

Figure 3. Pattern of forest utilization of the Talang Mamak Tribe, Riau Province, Indonesia. Note: 1. Yard, 2. Garden, 3. Field, 4. Sialang forest, 5. Rimba Simpanan; 1, 2, 3: private property, 4, 5: community poverty

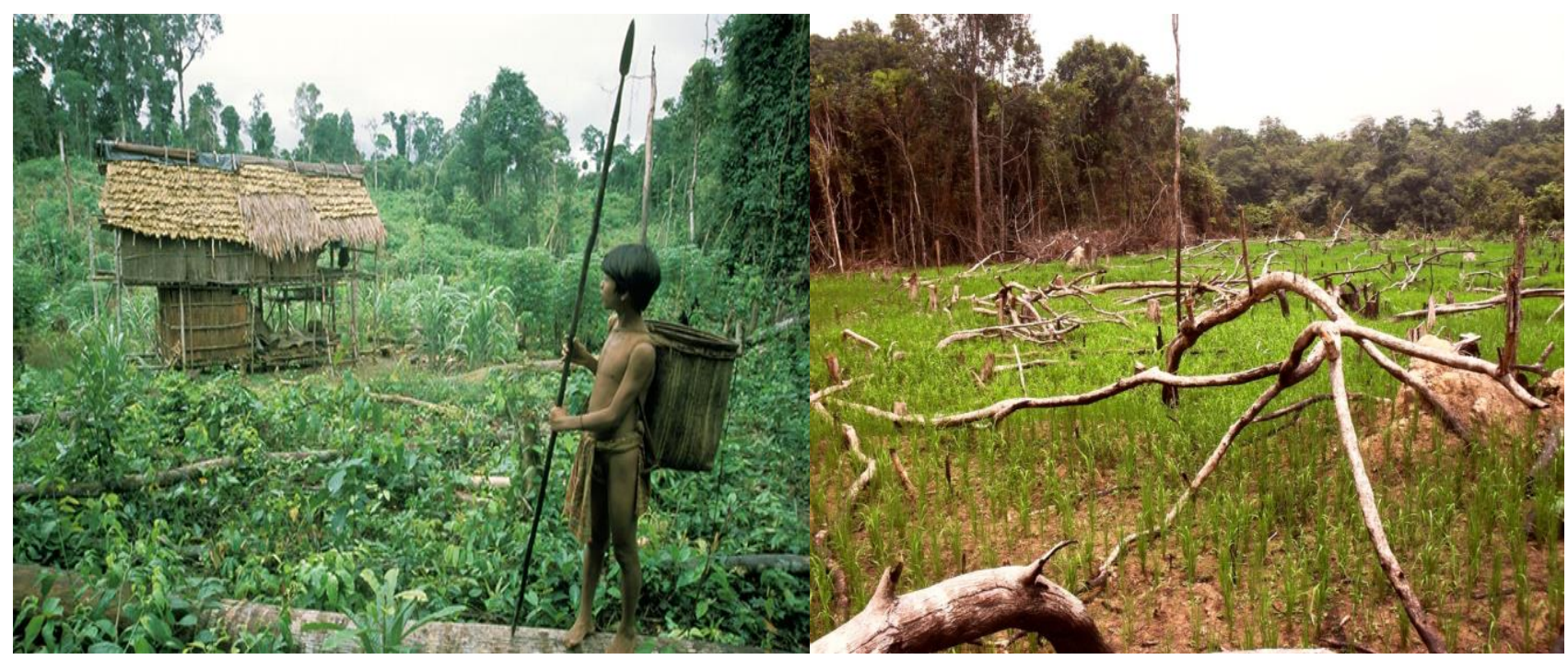

Figure 4. Fields and Talang Mamak Tribal Gardens, Riau Province, Indonesia 

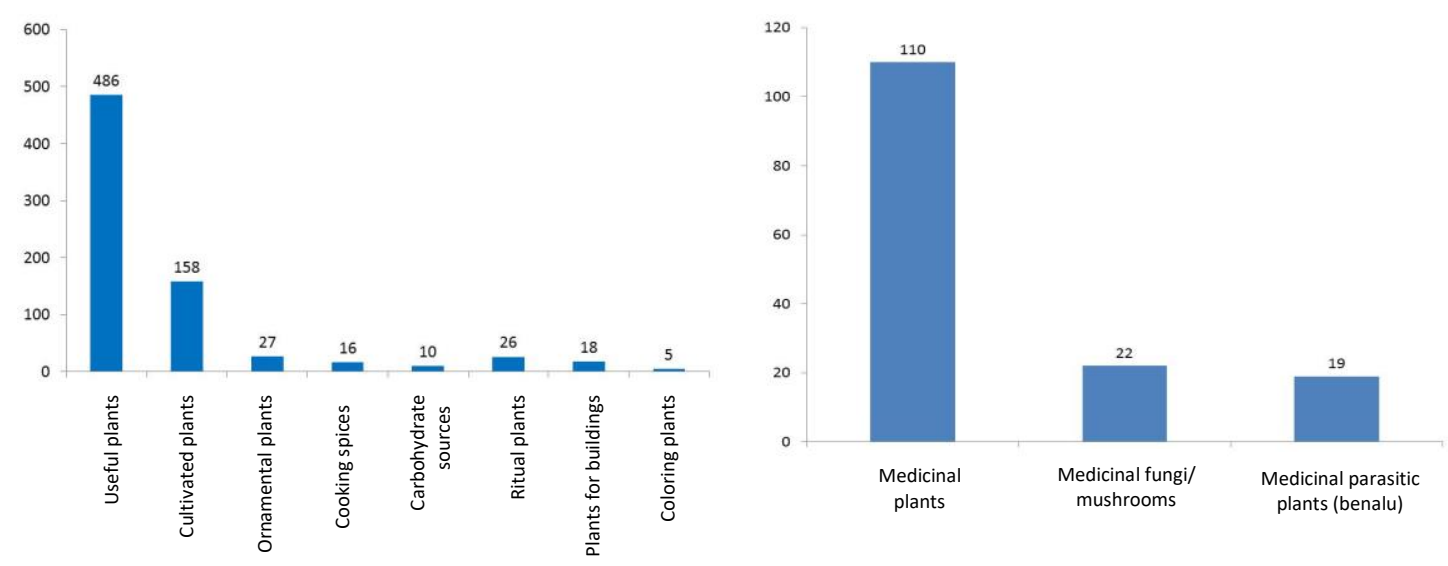

Figure 5. Species of plants utilized by the Talang Mamak Tribe, Riau Province, Indonesia

Based on the results of the inventory, there are 158 species of forest plants that are cultivated and 486 species of forest plants used by people living in and around the TNBT area. The species of plants that have been used consist of 27 species for ornamental plants, 16 for cooking spices, 10 for sources of carbohydrate, 5 for latex and resin producers, 26 for ritual and magical purposes, 18 for wood boards, 21 for building and 3 for coloring. Of the 660 species of plants that are used by local communities, an estimated $20 \%$ of which are obtained from virgin forests, $11 \%$ from logged-over areas, $29 \%$ from secondary forests, $15 \%$ from rubber forests, $5 \%$ from fields, and $19 \%$ from yards. Utilization of plants for medicinal purposes by traditional communities living in and around TNBT is common, and as many as 110 species of plants are utilized by the Talang Mamak Tribe to treat 56 kinds of diseases and 22 species of fungi to treat 18 kinds of diseases. From the richness of the flora, there are 51 species of medicinal plants and 8 species of medicinal fungi that have very good prospects for research and development. Some diseases that can be cured with traditional medicine include wound, worm infestation, flatulence, fever, dizziness, mouth sores, low back pain, stomach upset, toothache, insect bite, diarrhea, cold, ulcer, shortness of breath, coughing up blood, etc.

Plants are used as building construction materials, food ingredients, medicines, and in traditional and cultural ceremonies. The species of plants are used vary widely and are obtained from cultivation or extracting from the forest. There is a principle of traditional wisdom in the use of plants that are not cutting down trees that provide benefits for life such as trees used by bees to make nests and trees whose fruit is used, as well as rare species of plants that they know from the results of the initialization of TNBT managers. Community awareness to preserve the surrounding environment has contributed greatly to the preservation of that species. If the ban on use is violated, there are customary sanctions that are still being carried out to date. For example, cutting down durian trees is equivalent to one crime rate under killing.

TNBT areas have a high diversity of fauna, some of which are Sumatran endemic species. There are around 59 species of mammals in the TNBT area, 5 of which are endangered and protected by Indonesian laws and listed in CITES Appendixes and IUCN Redlist, namely beavers (Aonyx cinerea), clouded leopards (Neofelis nebulosa), tigers (Panthera tigris sumatrae), Sumatran elephants (Elephas maximus sumatranus) and tapir (Tapirus indicus), and there are three species found only in Sumatra, namely Siamang (Symphangus syndactylus), Sumatran Tiger and Malay Tapir. In addition, there are 18 species of bats dominated by fruit eaters from the Pteropodidae family. Based on the report of the Sumatran Tiger Conservation Program (PKHS) in TNBT, until 2007 there were no fewer than 32 species of large mammals from 14 families (not including the primate group) that inhabited the TNBT region. There were 9 primates from five families found in the TNBT area, namely Sumatran surili or simpai (Presbytis melalophos), monkeys (Macaca fascicularis), beruk (Macaca nemestrina), owa (Hylobates agilis), siamang (Hylobates syndactylus), langurs (Presbytis cristata), and gray lemurs (Nycticebus coucang).

The TNBT area has around 193 species of birds or almost half of bird species on the island of Sumatra. Some of these species are rare, namely stork storm (Ciconia stormi), tongtong stork (Leptoptilos javanicus), pecuk snake (Anhinga melanogaster), mentok rimba (Cairina scutulata), black quail (Melanoperdix nigra), sempidan merah (Lophura erythrophthalma), sempidan biru (Lophura ignita), large frogmouth (Batrachosstamus auritius), ivory hornbill (Buceros vigil), paok delima (Pitta granatina), and asi dada kelabu (Malacopteron albogulare). The species in TNBT classified as endemic to Sumatra are mentok rimba (Cairina scutulata), rangkong papan (Buceros bicornis), cucak kuning (Pycnonotus melanicterus), woodpecker (Trichastoma tickelli), and bondol tunggir putih (Lonchura striata). 
The Talang Mamak people utilize plants and wildlife to fulfill their daily needs. In making decisions about the use of natural resources, the role of traditional leaders and community leaders is very important. Whether or not a resource is used is decided by these traditional leaders. Preservation of biodiversity is guarded by indigenous peoples by utilizing the influence of these community leaders. Among indigenous people, the culture and leadership of the leaders strongly influence daily life, in hunting, farming, and other activities.

Utilization of more wildlife is done due to the need for animal protein sources and tools facilitates farming activities. There is no hunting intended to be sold out of the area. This condition was a success from the approach of the national parks and related NGOs (PKHS-Sumatran Tiger Conservation Program) to the traditional leaders of Talang Mamak. In general, the Talang Mamak people eat all kinds of animals except carcasses and Sumatran tigers and primates which are generally used as pets. When a resident will sell cattle out of the hamlet, a permission request ceremony is held for the tigers who are considered as their guardians. This ceremony is also intended for politeness because before someone raises livestock animals, permission from the shaman is needed, so if the livestock will be removed from the village it is better to ask permission.

The Sumatran tiger is an exalted animal and is not allowed to hunt. Tiger is considered a judge who will try people who have done wrong but are not punished by the law (in this case customary law). Talang Mamak people believe in the existence of a white tiger grandfather who is the king of tigers and a judge in the forest in the form of a mystical tiger with footprints the size of trays. This indigenous belief is the basis for tiger conservation in the traditional wisdom of the tribe.

The natural resource consumption by the Talang Mamak indigenous people is not too high. Traditional wisdom in shifting cultivation systems and semi-intensive cultivation only makes use of forest land in traditional use zones which are relatively insignificant. Regulation of the utilization of these resources, both ethnobotany and ethnozoology are still within the limits of reasonable and sustainable use. In managing this traditional use zone, the Bukit Tigapuluh National Park Office cannot prohibit the use of this community process. The right management step is assistance to the community so that the use of these resources does not deviate from meeting the needs.

Local wisdom of the Talang Mamak tribe in supporting the sustainable use of biological resources is a system of values and norms that prioritize aspects of sustainability and is the main capital of the community in building themselves, without destroying an adaptive social order with the surrounding environment. This happens because of their very high dependence on forest resources. This local wisdom-based forest management is a cultural heritage that upholds the principles of mutual trust, reciprocity and other general norms which are elements of social capital needed for the continuation of a good management order. Local wisdom of Talang Mamak Tribe in forest management can be divided into several components, including (i) planning;
The Talang Mamak community has local knowledge (land layout, namely settlements, farms, plantations and sacred land and traditional seasonal calendars), (ii) utilization; The utilization of forest resources is done by considering the sustainability, function, and productivity of forests (agroforestry systems), (ii) control; There are efforts to prevent, overcome and recover through abstinence with the control of customary leaders. (iv) maintenance; There are efforts to conserve forests through a system of mutual cooperation and belief in myth, (v) supervision; There are structure and function of adat leaders and (vi) law enforcement; Talang Mamak customary law regulates the existence of sacred land.

The Talang Mamak Tribe community considers that the forest and its contents are not only a source of livelihood, but also a source of culture and philosophical symbols, and even become their "identity" and "spirit". Their cultural elements and symbols show their union with nature, which they implement in various traditional expressions, ceremonies, and traditions. Planning and concepts in culture-based forest management can be seen from the land use of the Talang Mamak Tribe, which includes settlements, farms, plantations, and sacred lands. This use is based on regulated rights, historical and cultural importance, ecological nature and economic and spiritual use. This forest area has minimal access, so disruption to the structure and function of its ecosystem can be prevented. This is important, given the function of forests as supporting system for their productivity and inherited habitats that must be maintained.

The utilization of forest resources is carried out by considering the sustainability, function, and productivity of forests. One of the efforts made by the Talang Mamak Tribe is to make mixed gardens with forest plants, or agroforestry. This mixed garden is formed on former natural forest or scrubland. At the beginning of the rainy season, land is planted with rice that is mixed with other annual crops (e.g. corn, sweet potatoes, cucumber, and chili). After that, intensification of land use is increased by planting trees such as rubber or other perennials. When the trees are mature, the Talang Mamak Tribe community combines a variety of other annual crops that are beneficial in terms of economy and culture. Native forest plants that are beneficial are still allowed to grow naturally again, and are maintained among the main plants. Integration of agriculture, plantations, and forests in agroforestry systems results in a variety of benefits, including: (i) the fallen leaves from trees are useful as soil cover (mulch), increasing the supply of nutrients that are useful for annual crops; (ii) tree roots help in nutrient recycling; (iii) the weeds decrease through shade, and in the dry season the risk of fire also decreases due to higher moisture; (iv) the stability of the microclimate is maintained (reduce wind speed, increase soil moisture and provide partial shade); (v) the soil organic matter content increases and the soil structure improves so as to reduce erosion hazards.

Almost all aspects of the Talang Mamak Tribe life are always related to forest products, both for primary needs such as food and shelter, as well as secondary needs such as knitting ropes, tools, and traditional rituals. The various 
forest resources utilized by the Talang Mamak Tribe community are produced from sacred land and fallow land, namely agricultural land that is not being planted in a certain period, with the aim of restoring fertility. Most of the utilization is only for subsistence. This will indirectly guarantee the sustainability, function, and productivity of forests because there is no excessive exploitation of forest resources.

Control in forest management carried out by the Talang Mamak Tribe community involves all components of society and customary leaders. Batin and his ranks lead this control. Batin plays an important role as in the following phrase "clears the cloudy, completes the tangled, straightens the crooked, directs the knotted, loosens the tightened". Previously, the one who played an important role in adat was Patih, but in subsequent inheritance, after the third generation (grandchild of Datuk Perpatih nan Sebatang), there was a change and the pattern of leadership was passed on not through more children, but through the path of his niece, the highest title of leader was no longer Patih but is replaced by Batin. There are 29 Batin in Talang Mamak community, including Gajian (Batin Gedabu), Irasan (Batin Paret) and Iskandar (Batin Pejangki).

Preventive measures include ban for cutting flowering and fruiting trees, few species of trees and sialang trees. This is based on their awareness that all of these forest resources are entrusted by ancestors and will be passed on to their offspring. Countermeasures such as abstinence in farming are mostly using land in forest areas, land clearing and utilization must minimize damage. This is motivated by a cultivation culture that is at the core of their culture.

The tools and equipment used by the Talang Mamak Tribe community in their work have been designed and used with a natural perspective. Tools and equipment used are pickaxe (to cut), axes (to divide), beliung (to cut), tajak (to weed), sabit (to cut grass) and tembilang (to dig). There are no tools and equipment that have the potential to damage the environment, because the power capacity is very small and the impact of a tool is determined by the human resources who use it.

The myths related to forest management can be seen from the various rituals that they carry out such as melambas to clear land, namely burning incense and placing dishes in locations that will be cleared and left them there for three days. If the dish remains intact, they are allowed to clear the land. Myth also accompanies the preservation of various species of sialang trees, which are strongly protected even often believed to be sacred trees. The Talang Mamak Tribe community believes that only the trees that have a "watchman" (which is inhabited by spirits) will be visited by bees to make a nest; the "watchman" protects the beehives from interference. Therefore, when the Talang Mamak tribe community carries out a menjumbai activity (harvesting honey), they must obtain the permission of the customary leader and the implementation is led by the juagan. In the practice of working the fields, the Talang Mamak Tribe always cooperates, in terms called basolang menugal which is carried out jointly by all members of the community at the beginning of the land clearing until it is finished.
The Talang Mamak Tribe community adheres to ancestral customs and traditions in managing forests as a source of life. Talang Mamak tribe has a leader called Batin. Batin and its ranks act as the highest authority and determine all regulations that apply in society. Batin title is passed on to the nephew or grandson who has certain signs. In other words, the person who becomes the heir to the title can already be seen from his personal characteristics and not everyone can be Batin.

The Talang Mamak Tribe value system relies on adat and resam (tradition). Adat is protected by traditional institutions led by Batin with the ranks of adat leaders who help him. Customs that have been passed down from generation to generation consist of norms and sanctions and are carried out with the principle of "tiered up stepping down". That is, each case must be resolved first by the lowest power/layer. If it's not finished, then proceed to the level above it. Common property does not necessarily make forest resources have open access. The traditional institution of the Talang Mamak Tribe fulfills the basic prerequisites regarding the management of shared natural resources, namely: (i) clear boundaries; (ii) rules regarding management in accordance with local conditions and (iii) a number of sanctions are applied if there are violations of the rules.

The customary law of the Talang Mamak Tribe explains that to decide something, they must go through deliberation and consensus by the customary leaders who have the right to refuse or accept a decision, and this is what is said in the customary phrase "the just king is the king who is worshiped, the king of wrongdoer is denied". Every decision that concerns the interests of the people can be tested for truth, fair, proper or appropriate, so that the leader does not lose the trust of the community, so a leader/ruler who is just and proper or appropriate in deciding is stated in the custom: "if round can be overthrown, flat can be filed, white conditions, red can be seen, length can be measured, weight can be weighed".

Customary law is enforced very tightly and remains valid. The customary law of the Talang Mamak tribe is written and kept in verbal rules (petitah petitih). Communities that commit forest destruction such as logging, land clearing or hunting wild animals in excess will be prosecuted and processed in stages ranging from the village level to the adat level. The customary law of the Talang Mamak tribe regulates the existence of sacred land, for those who take forest products or cut down trees, a fine called pancung alas will be imposed.

In conclusion, local wisdom of the Talang Mamak tribe is reflected in managing and utilizing bioresources, that include local knowledge in the planning aspect. Utilization of bioresources is carried out by considering the sustainability, function, and productivity of forests. Control includes prevention, mitigation, and recovery through prohibition with the control of customs leaders. Maintenance includes reserve and forest conservation through a system of mutual cooperation and belief in the myth and the existence of customary law governing the existence of sacred land (tanah keramat). The value of local wisdom found in the Talang Mamak Tribe is the civic 
culture value such as patriotism, equality, concern, responsibility, independence, and kindness.

\section{REFERENCES}

Ade V, Affandi I. 2016. Implementasi nilai-nilai kearifan lokal dalam mengembangkan keterampilan kewarganegaraan (Studi deskriptif analitik pada masyarakat Talang Mamak Kec. Rakit Kulim, Kab. Indragiri Hulu Provinsi Riau). Jurnal Pendidikan Ilmu Sosial (25)1: 77-91. [Indonesian]

Anil MNV, Kumari K, Wate SR. 2014. Loss of biodiversity conservation strategies: an outlook of Indian Scenario. Asean J Conserv Biol 3 (2): 105-114.

BBKSDA Riau. 2013. Area Konservasi di Riau. Balai Besar Konservasi Sumber daya Alam Riau, Pekanbaru. [Indonesian]

Chakravarty S, Ghosh SK, Suresh CP, Dey AN, Shukla G. 2012 Deforestation: Causes, Effects and Control Strategies, Global Perspectives on Sustainable Forest Management, Intech, Rijeka, Croat.

Díaz S, Fargione J, Chapin FS III, Tilman D. 2006. Biodiversity loss threatens human well-being. PLoS Biol 4 (8): e277. DOI: 10.1371/journal.pbio.0040277.

Gilung. 2012. Talang Mamak: Hidup Terjepit di atas Tanah dan Hutannya Sendiri-Potret Konflik Kehutanan antara Masyarakat Adat Talang Mamak di Kabupaten Indragiri Hulu Provinsi Riau dengan Industri Kehutanan, Disampaikan sebagai bahan pelengkap kesaksian dalam sidang pengujian UU 41 tahun 1999 tentang kehutanan. [Indonesian]

He J, Yan C, Holyoak M, Wan X, Ren G, Hou Y, Xie Y, Zhang Z. 2018. Quantifying the effects of climate and anthropogenic change on regional species loss in China. PLoS One 13 (7). DOI 10.1371/journal.pone.0199735

Heilpern SA, Weeks BC, Naeem S. 2018. Predicting ecosystem vulnerability to biodiversity loss from community composition. Eco Soc Amer 99 (5): 1099-1107.
Hussein MA. 2008. Cost of Environment Degradation: An Analysis in the Middle East and Nort of African Region. Manag Environ Qual 19 (3): 305-317.

Johnson NC, Balmford A, Brook BW, Buettel JC, Galetti M, Guangchun L, Wilmshurt JM. 2017. Biodiversity losses and conservation responses in the Anthropocene. Science 356: 270-275.

Junior CHLS, Arágao LCOE, Fonseca MG, Almaeda CT, Vedovato LB, Anderson LE. 2018. Deforestation-Induced Fragmentation Increases Forest Fire Occurs in Central Brazillian Amazonia. Forest 9 (8): 305.

Mastel M, Bussalleu A, Paz-Solda' VA, Mulanovich GS, Velasquez AV, Hartinger SM. 2018. Critical linkages between land use change and human health in the Amazon region: A scoping review. PloS One DOI: 10.1371 journal.pone.0196414

Mauludea, Nurhadianto H, Islamuddin. 2016. Budaya masyarakat Suku Talang Mamak dalam bagian civic culture. Jurnal Edukasi, 14 (1)1: 53-68. [Indonesian]

Muntaza. 2014. Silang-Sengkarut: Perjuangan Tanah Air Orang Talang Mamak. Kertas Kerja Sajogyo Institute No. 4/2014. Sajogyo Institute, Bogor. [Indonesian]

Ojo BS, Alaye SA, Bouchuama A, Martins A. 2018. Influence of Deforestation in Borgu Local Goverment Area of Niger State, Nigeria. World News Nat Sci 18 (2): 62-71.

Santoso J. 2008. Rubber Production System by Talang Mamak and Melayu Tua Living in Bukit Tigapuluh National Park, Indonesia: The correlation between its contributions to household objectives and its pressure on BTNP sustainability. [Thesis]. Graduate School of Science and Technology, Niigata University, Japan.

Singleton W. 1998. Old Ways-New Ways: Talang Mamak of Tiga Balai, Inderagiri Hulu, Propinsi Riau, Sumatra. [Dissertation]. University of St. Andrews, UK

Titisari PW, Syamsudin TS, Sjarmidi A. 2016. The utilization of bioresources by local communities at Giam Siak Kecil-Bukit Batu Biosphere Reserve, Riau Province, Indonesia. Biodiversitas 17 (2): 873-886.

Tyagi S, Garg N, Paudel R. 2014. Environmental Degradation: Causes and Consequences. Kurukshetra University, Kurukshetra 